International Review of Social History 44 (1999), Supplement, pp. I-13

(C) 1999 Internationaal Instituut voor Sociale Geschiedenis

\title{
Complicating Categories: An Introduction
}

\author{
EILEEN Boris AND ANGÉLIQUE JANSSENS
}

This 1999 Supplement of the International Review of Social History focuses on complicating central concepts in the understanding of economic and social history: class, gender, race and ethnicity. In concentrating on industrial workers, their politics, and institutions, labor and working-class history had tended to ignore gender, race, and ethnicity as discursive and material forces. It discussed the woman or black or immigrant worker as a subset of worker, assumed to be male, white, and of the dominant national or ethnic group. Only during recent years have historians began to ask how gender, race, and ethnicity as categories of analysis change narratives of class formation and working-class experience. This question has become particularly salient as the European Union and the United States seek to grapple with the human consequences of colonial and imperialist legacies both within and beyond national boundaries in an increasingly global economy.

Over the last few decades, feminist scholarship has demonstrated most powerfully the analytical power of gender to disrupt conventional understandings of worker identity, class formation, proletarianization, and a host of other prominent issues. Simultaneously, it has shifted the terms of discussion from the workplace to the home and family and back to other locations of labor. Its findings have seriously undermined the class paradigm in the study of labor and working-class history. We have moved beyond debating the explanatory primacy between class and gender to consider their mutual constitution. Still the field has more often studied gender apart from race and ethnicity, marking woman as belonging to the dominant racial or ethnic group as surely as labor history had treated the worker as male, and ignoring the ways that racial and ethnic differences turned class or gender divisions into solidarities.

More recently, scholarship on "race" and ethnicity as sometimes related and sometimes distinct categories of analysis (depending on time and place) has expanded knowledge of class formation and gender construction. These developments have led scholars and activists to question the precise relationship between all of these concepts and the possibilities or impossibilities to unite and/or integrate them. What would this process of integration look like? What kinds of historical insights and histories would emerge from such a process of integration? Or is integration even the appropriate metaphor for interrogating the meaning of each of these categories in itself and in relation to the others? This Supplement highlights attempts to write a richer history that complicates categories, suggesting how class, gender, race and/ or ethnicity combine across a wide range of economic and social landscapes. 


\section{GENDER, RACE AND THE NEW LABOR HISTORY}

The now old new labor history came of age with a silence at its core. In the excitement of recovering the culture and agency of laboring people, it failed to recognize the actual subject of working-class history. In their survey of labor history before gender analysis, Laura L. Frader and Sonya O. Rose have found "a story of exclusions" - of women and non-whites, whether native-born, colonial, or immigrant. Working-class women were marginal, for example, to E.P. Thompson's magisterial Making of the British Working Class. As Joan Wallach Scott argued, Thompson constructed class "as a masculine identity, even when not all the actors were male". Indeed, Scott exposed the gendered dynamic at the heart of Thompson's story: the coding of work, production, and "rationalist" politics as male and the locating of domesticity, coded as female, as "outside production" and connected to expressive religious movements that undermined "true" class consciousness. ${ }^{3}$

In parallel fashion, David Roediger returned to the pioneering insights of W.E.B. Dubois to chart "the wages of whiteness" that were all but ignored by Thompson's American followers who focused on artisanal labor. But Roediger did not merely point out racial silences in texts or the ways that some workers constructed themselves as white against the black slave. His critique of the new labor history condemned its "overemphasis" on class over race. Its main narrative had black as well as white workers acting on the basis of class interests over cultural or racial ones, as if the former was not framed by the later - and both by gender, as we argue throughout this volume. ${ }^{2}$

By the time Scott's critique appeared, a growing band of women historians were already casting women into the story of working class formation as active agents on their own terms. While most contextualized their studies in light of worksite, ethnicity, and other sociodemographic factors, whiteness lurked as a subtext with the black or racial ethnic worker a special case of the woman worker. ${ }^{3}$ By focusing on the dyad male and

I. Laura L. Frader and Sonya O. Rose, "Introduction: Gender and the Reconstruction of European Working-Class History", in Laura L. Frader and Sonya O. Rose (eds), Gender and Class in Modern Europe (Ithaca, NY, 1996), p. I0; Joan Wallach Scott, Gender and The Politics of History (New York, 1988), pp. 72, 79. See also Sally Alexander, "Women, Class, and Sexual Difference", History Workshop, 17 (1984), p. 131.

2. David R. Roediger, The Wages of Whiteness: Race and the Making of the American Working Class (New York, 1991); idem, "Labor in White Skin': Race and Working Class History", in David Roediger, Towards the Abolition of Whiteness (London, 1994), p. 25; idem, "The Crisis in Labor History: Race, Gender and the Replotting of the Working Class Past in the United States", in Towards the Abolition of Whiteness, pp. 69-8r. Similarly, see Herbert Hill, "The Problem of Race in American Labor History", Reviews in American History, 24 (1996), pp. 189-208; Nell Irvin Painter, "The New Labor History and the Historical Moment", International Journal of Politics, Culture, and Society, 2 (1989), pp. 369-370.

3. Evelyn Brooks Higgenbotham, "African-American Women's History and the Metalanguage of Race", Signs: A Journal of Women in Culture and Society, 17 (1992), pp. 251-274; Dana Frank, "White Working-Class Women and the Race Question", International Labor and Working-Class History, 54 (1998), pp. 80-102. 
female, feminist thought during the 1970 and 1980 s replicated exclusions of race, ethnicity, and nation that distorted working-class history as a whole. For many sought to supplement class analysis by turning to the concept of patriarchy as a system in which men as a sex group controlled the productive and reproductive labor power of women. And patriarchy was a concept blind to race and ethnicity. These writers concluded that women's oppression emanated not from industrial capitalism but predated it and indeed its locus lay elsewhere. Patriarchy, more than capitalism, had kept women subordinated. By the early eighties, however, attempts to integrate a feminist analysis of patriarchy with the Marxist analysis of class had produced an unhappy marriage on the verge of divorce. Some questioned the interpolation of the term patriarchy to class society in the first place; others rejected dual systems theory as replicating Victorian notions of separate spheres and saw gender "imbricated" in economic and social systems as a whole. ${ }^{4}$ While theorists moved in separate directions, with class analysis suffering a crisis from the collapse of the eastern-European communist regimes and the weakening of traditional labor movements, gender emerged into the analytical limelight by the early I990s.

Initially women's labor history, focused on the last two centuries, had charted occupational segregation by sex, trade union exclusions, and employer exploitation. It further recovered the history of women as wage earners and their roles in productive as well as reproductive or family labor. It highlighted the relationship between female wage earning and capitalist development, the family wage and trade unionism. ${ }^{5}$ These were materialist histories, sure that they had captured women's experiences and voices even as they questioned the terms of labor and working-class history. What did deskilling mean for women, defined as unskilled in the first place? Perhaps women's skill just was unrecognized because others determined the boundaries of "skill". The public/private dichotomy broke down, or at least became more complex. The home stood as a workplace not only for the family but also for the market. It became a space not only for the fashioning of goods but also for the making of people, a socialization process as significant to class formation and resistance as the housewife's indirect work for the employer. Resistance no longer belonged only to unions and parties but occurred in the family. Consumption became a site of struggle. ${ }^{6}$

4. For history, Alice Kessler-Harris, Out to Work: A History of Wage-Earning Women in the United States (New York, 1982); Joan Wallach Scott and Louise Tilly, Women, Work, and Family (New York, 1978); for theory, Michele Barrett, Women's Oppression Today (London, 1980); Lydia Sargent (ed.), Women and Revolution: A Discussion of the Unhappy Marriage of Marxism and Feminism (Boston, MA, 198I); Sylvia Walby, Theorizing Patriarchy (Oxford, 1990). For the dual systems critique, Frader and Rose, "Introduction", p. I9.

5. For one summary of old and new directions, Pamela Sharpe and Harriet Bradley (eds), Labour History Review, 63 (1998), special issue on "Gendering Work: Historical Approaches".

6. Excellent summaries of the literature are found in Frader and Rose, "Introduction", and the remaining essays in Gender and Class in Modern Europe; see also Ava Baron, Work Engendered: Toward a New History of American Labor (Ithaca, NY, 1991). For the home, Eileen Boris, "The 
This gender turn came in tandem with the linguistic turn. To the dismay of some, gender exists even without women. Attention to manhood and masculinity as well as a concern with gender as a marker of difference and signifier of power has distinguished literature that relies on gender as a category of analysis. So has a shift to the cultural, an emphasis on meaning derived from understandings of gender as a process or relation, one that shapes institutions no less than characterizes representations. Certainty as to voices and experiences disintegrated, as identity became more negotiated and less fixed. These developments also tended to disrupt certainty as to the meaning of class, race and ethnicity. ${ }^{7}$

Gender itself stands in conjuncture with other social signs - class, race, ethnicity, and sexuality - in ways that are still being problematized. In part, this trajectory - from description to theorization - follows a necessary course. Empirical research deepens analysis. But this trajectory also reflects the history of feminist scholarship itself. Having cast aside Marxist accusations of neglecting class differences between women, feminists increasingly found themselves under attack for ignoring differences of race and ethnicity. The universalizing rhetoric of gender claimed to embrace all women when in fact it derived from the standpoint of usually middle-class white women in North America or northern Europe. These claims had no reality for women of color faced with a set of problems resulting from their gendered positions within specific ethnic or racial communities as well as their racial position within the larger society. ${ }^{8}$ White women in the metropoles partook of white privilege based on the exploitation and oppression of women of color at home and abroad. During the last century and a half, the labor of women of color in domestic, service, and other low-waged work has enabled white women to gain leisure or enter the workplace, usually on better terms than those available to racial "others".?

Despite a rich historical literature on women of color in the United

Home as a Workplace: Deconstructing Dichotomy", International Review of Social History, 39 (1994), pp. 415-428.

7. Scott, "Gender: A Useful Category of Historical Analysis", in Gender and the Politics of History, pp. 28-52; Ava Baron, "On Looking at Men: Masculinity and the Making of a Gendered WorkingClass History", in Ann-Louise Shapiro (ed.), Feminists Revision History (New Brunswick, NJ, 1994), pp. 146-17I.

8. Some recent critiques include Ann duCille, "The Occult of True Black Womanhood: Critical Demeanor and Black Feminist Studies", Signs: A Journal of Women in Culture and Society, in (1994), pp. 59I-629; Susan Stanford Friedman, "Beyond White and Other: Relationality and Narratives of Race in Feminist Discourse", Signs: A Joumal of Women in Culture and Society, 2I (1995), pp. I-49; see also Chandra Talpade Mohanty, "Under Western Eyes: Feminist Scholarship and Colonial Discourses", in Chandra Talpade Mohanty, Ann Russo, and Lourdes Torres (eds), Third World Feminisms and the Politics of Feminism (Bloomington, IN, 1991), pp. 5I-80.

9. For example, Phyllis Palmer, Domesticity and Dirt: Housewives and Domestic Servants in the United States, 1920-1945 (Philadelphia, PA, 1989). 
States, much of it focused on work, family, and politics, ${ }^{10}$ the historiography of class and race often considers gender as an afterthought. ${ }^{\text {II }}$ Eric Arnesen noted in 1998 that race and class represents "an academic growth industry" ${ }^{12}$ US labor historians have addressed "the intersections of race and class, racial segmentation of the labor marker, and the impact of race on culture and community", Alan Dawley and Joe William Trotter, Jr previously explained. ${ }^{13}$ With theories of social constructionism discrediting biological explanations for racial difference, the historicizing of race in a period of multiculturalism has framed this burgeoning literature. "White" not only developed in relationship to the category "black", but definitions of "white" have changed over time and place. In some cases, class advancement whitens individuals. And the binary of white/black embraces only some racial hierarchies. The construction of race has differed among Anglo-American societies as compared to Iberian ones, for example. The burgeoning whiteness literature has explored European ethnic groups in the United States as "inbetween people", explaining the development of "whiteness of another color" and "how Jews became white folks". ${ }^{\mathrm{t4}}$

To their credit, Dawley and Trotter recognize that race "is about kinship, courtship, recreation, education, and who marries whom - in short, social reproduction". Is Martha Hodes more recently has asserted: "the history of

10. Notable examples include Jacqueline Jones, Labor of Love, Labor of Sorrow: Black Women, Work, and the Family (New York, I985); Tera W. Hunter, To Joy My Freedom: Southern Black Women's Lives After the Civil War (Cambridge, MA, 1997); Evelyn Nakano Glenn, Issei, Nisei, War Bride: Three Generations of Japanese American Women in Domestic Service (Philadelphia, PA, 1986); Vicki L. Ruiz, Cannery Women, Cannery Lives: Mexican Women, Unionization, and the California Food Processing Industry, 1930-1950 (Albuquerque, NM, 1987); Laura Tabili, We Ask for British Justice: Workers and Racial Difference in Late Imperial Britain (Ithaca, NY, 1994) genders black working-class men. Recent work in Australia also has reclaimed the history of Aboriginals. See Ann McGrath and Kay Saunders, with Jackie Huggins, "Aboriginal Workers", special issue of Labour History, 69 (1995).

II. For example, the forum on Bruce Nelson, "Class, Race, and Democracy in the CIO: The 'New' Labor History Meets the 'Wages of Whiteness', International Review of Social History, 4I (1996), pp. 35I-374, which dismisses the comments of Elizabeth Faue.

I2. Eric Arnesen, "Up from Exclusion: Black and White Workers, Race, and the State of Labor History", Reviews in American History, 26 (1998), pp. 146-147.

13. Alan Dawley and Joe William Trotter, Jr, "Race and Class", Labor History, 35 (1994), p. 486. 14. James R. Barrett and David Roediger, "Inbetween Peoples: Race, Nationality and the 'New Immigrant' Working Class", Journal of American Ethnic History, 16 (1997), pp. 3-44; Mathew Frye Jacobson, Whiteness of a Different Color (Cambridge, MA, 1998); Karen Brodkin, How Jews Became White Folks and What That Says About Race in America (New Brunswick, NJ, 1998); Raymond Gutierrez, When Jesus Came, the Corn Mothers Went Away: Marriage, Sexuality and Power in New Mexico, 1500-1846 (Stanford, CA, 1991).

15. Dawley and Trotter, Jr, "Race and Class", p. 492. For examples, Kevin Boyle, "The Kiss: Racial and Gender Confict in a 1950s Automobile Factory", Journal of American History, 84 (1997), pp. 496-523; Eileen Boris, "You Wouldn't Want One of 'Em Dancing With Your Wife': Racialized Bodies on the Job in WWII", American Quarterly, so (1998), pp. 77-108. 
racial categories is often a history of sexuality as well ${ }^{16}{ }^{16}$ Indeed, race itself is gendered. As Tessie Liu also contends, it "functions through controlling sexuality and sexual behavior ${ }^{n}{ }^{17}$ Race and gender share much as categories of analysis - both are socially constructed through the assignment of meaning to bodies and thus take material forms in their terms as well as their consequences. But their functioning within social formations varies, as does their relationship to and reformulation of class.

\section{COMPLICATING CATEGORIES}

Race, gender, and class may be conceptualized as systems of domination or systems of inequality. But they may also be cultural identities. How do these systems of difference relate to each other? Despite a growing empirical literature, authors more often connect dyads rather than consider historical phenomenon from the tryad of class, race, and gender. ${ }^{18}$ The category of race has served to divide white women from women of color, while the category of gender has separated non-whites into males and females. Differences in class distinguish both racial and gender groups. Meanwhile, definitions of deviant gender relations and behaviors have shaped racial relations and racial systems of domination. These are contingent, provisional categories and identities. Their form and content differ according to time, place and historical circumstances, but also depend on the dimensions of experience and identity that the historian wishes to illuminate.

However, bringing all three factors into the analysis is extremely difficult. Feminist theory, as Ann Curthoys has argued, inclines to focus on gender as the primary concept, viewing class or race/ethnicity as secondary distinctions. If treating gender together with either race or class is not already difficult, trying to bring into play a third factor makes the analysis too complex to handle. To circumvent what Curthoys calls "the three body problem", we need to reject conceptions of race, class and gender as three separate structures of domination, which can just be "added on" so that black working-class women are constructed as threefold oppressed, as women, as blacks and as working-class. Rather each of these experiences and relationships influences the others, transforming the meaning of what it means to be black, to be a woman or to be working-class. So if we start

16. Martha Hodes, "Introduction: Interconnecting and Diverging Narratives", in Martha Hodes (ed.), Sex, Love, Race: Crossing Boundaries in North American History (New York, 1999), p. I; see also Peggy Pascoe, "Miscegenation Law, Court Cases, and Ideologies of 'Race' in TwentiethCentury America", The Journal of American History, 81 (1996), pp. 44-69.

17. Tessie Liu, "Teaching the Differences Among Women from a Historical Perspective: Rethinking Race and Gender as Social Categories", Women's Studies International Forum, 14 (1991), p. 271. 18. For one attempt that privileges race, Floya Anthias and Nira Yuvaly-Davis with Harriet Cain, Racialized Boundaries: Race, Nation, Gender, Colour and Class and the Anti-Racist Struggle (London, 1992). 
by considering race and class in a dyadic approach, each of these influences the other. However, if we bring a third factor seriously into play, such as gender, the third term will influence the second and therefore the first in such a way that the original basis for the analysis changes and one has to start all over again. ${ }^{\text {t9 }}$

Ethnicity sometimes designates the other instead of race, especially otherness associated with nation, citizenship, religion, or culture. Sandra E. Greene notes in her contribution that definitions of the "ethnic other" change under the influence of political and demographic developments that relate to social hierarchies and family formation. Essays by Michele Mitchell, Raelene Frances, and Fatima El-Tayeb particularly highlight the conjuncture of race and citizenship in colonial or imperial settings. United States historiography especially distinguishes race from ethnicity. Ethnic conflict occurs between European immigrants, seen in Ileen A. DeVault's study of cross-gender strikes. Some Europeans were not always judged to be white, as Frances shows for Australian immigration policy. ${ }^{20}$

History reveals the instability of these categories, warning against any reification of them. Within one and the same boundaries of time and space, gender or race may don many meanings. Race, class, and gender do not conform to categories that exist in and by themselves. However, the inherent instability of categories should not automatically lead us to the postmodernist assumption that these categories do not exist outside of the historian's texts. Race, class and gender do structure people's lives, their relationships with other individuals and/or groups and the objects surrounding them. Moreover, since these categories structure domination and inequality, this automatically implies that social, economic and political resources are divided unequally between the groups distinguished by such categories, as is demonstrated by Laura Dudley Jenkins in her paper on Indian women.

The instability of categories such as race, class and gender becomes apparent when one category becomes inflected by another. Laura L. Frader, for example, demonstrates what happens when race mediates gender. In early twentieth-century France, the gender of Asian male workers became "feminized" through an association with softness and submissiveness. Class, race and gender intertwined to the extent that Asian workers could never qualify as "real men". Often loss of masculinity denotes race and class oppression. Fighting for group liberation becomes a way to express real manhood, but just plain fighting will do, as Mitchell uncovers among elite and aspiring class African-American men a century ago.

What about women? Men have taken the category ethnicity/race away

19. Ann Curthoys, "The Three Body Problem: Feminism and Chaos Theory", Hecate, 17 (1991), pp. I4-2I.

20. See also Ruth A. Frager, "Labour History and the Interlocking Hierarchies of Class, Ethnicity, and Gender", International Review of Social History, 44 (1999), pp. 217-247. 
from women, who at the same time are responsible for maintaining ethnicl racial identity. Does this work of race serve to maintain gender systems? Certainly white men used racial difference to discipline women of their own race and class by constructing racialized sexual identities in which white women represent chastity and women of color, promiscuity. These representations operate to ensure the sexual control of white women while justifying the sexual exploitation of women of color by white men. Whiteness, as well as blackness, is profoundly gendered. Still whiteness functions in relation to class, with behavior and character traits parceled out on the basis of social position as well. ${ }^{21}$

The privileges of whiteness have differed by gender and class. In demanding equal rights, white women threaten white men's control of racialized definitions of gender. White men may then stress normative gender systems which demand greater effort by whites. Working-class men, El-Tayeb suggests, benefit from their maleness in the process. This German example nicely demonstrates the "intersectionality" of gender and race. For women of color, however, positioning themselves in one system of struggle/ inequality also situates them in another system of inequality. They have to become engaged in a complex constellation of different interrelated struggles for power. Women of color therefore are caught between competing and unstable systems of male domination. White men try to regulate systems of race, gender and class to ensure their position within a classified, racialized, and gendered system of privileges. In response, men of color may try to regulate their own system of inequality based on gender divisions to ensure the continuation of family and community lives and to construct a politics of resistance in their struggle within the racialized system of inequality. Women of color identify more with men of their group than with white women. These processes exist for other ethnic, religious, and group divisions, as Jenkins's discussion of India reveals.

These divisions among women, and within ethnic or racial groups, derive from the relationships of these groups to the white men who hold much of the power in Western societies. The idea that these divisions come solely from the relationships between or within these social groups only operates to sustain the legitimacy of white men's power, can ignore the privileged status of white women, and precludes an analysis that takes into account the complex interrelationships between all three systems of inequality. It tends to hide the workings of class in the conflation of class with gender and race.

21. Julia Clancy-Smith and Frances Gouda (eds), Domesticating the Empire: Race, Gender, and Family Life in French and Dutch Colonialism (Charlottesville, VA, 1998); Earl Lewis and Heidi Ardizzone, "A Modern Cinderella: Race, Sexuality, and Social Class in the Rhinelander Case", International Labor and Working-Class History, s1 (1997), pp. 129-147. 


\section{INTERSECTIONALITY, SERIALITY, MATERIAL IDENTITIES}

The collected essays divide into two loose groupings. The first - Greene, DeVault, and Jenkins - offers three approaches to complicating categories. The next four - Mitchell, Frances, Frader, and El-Tayeb - address the conjuncture of racialized gender and sexuality in relation to colonialization and nation-building. Class is present but undertheorized as these scholars highlight the ways that race and gender define citizenship within diverse class societies - post-emancipation United States on the verge of imperial prominence and in the consolidation of legalized segregation, settler-state Australia, World War I and 1920 s France, and Germany in three periods.

Pre-colonial Africa constructed hierarchy in ways distinguished from modern capitalist society. It measured social stratification through lineage, age, ethnicity, and religion, all of which shaped the meaning of gender. Elder women in the lineage could hold power over younger men, sisters over wives. The means and mode of production, and indicators of wealth, also differed. Religious authority, for one, functioned as an important source of power and prestige. Through analysis of eighteenth- and nineteenthcentury Anlo society (in what is now Ghana), Sandra E. Greene advances the approach of intersectionality, most associated in the United States with the legal studies movement of critical-race feminism. Arguing against an additive model of race, gender, and class, such scholars consider all of these components together as part of a single identity. ${ }^{22}$ Greene explores the intersections between gender and ethnicity, moving African women into the middle of the concept of ethnicity. She counters the construction of ethnicity as something belonging to men and the political bodies that they regulated, a bias in African history analogous to conceptions of class and class formation within histories of capitalist societies.

In this account, gender and ethnicity operate as systems of identification invoked to confront social transformations generated by warfare, the slave trade, political instability, and the resulting influx of large numbers of immigrants. Greene demonstrates the important ways in which gender and ethnicity intersected and the ways in which gender, through marriage choice and household relations, contributed to the process of defining and redefining the "ethnic other". Both men and women were active agents that helped support or undermine boundaries distinguishing "us" and "them", including young women who joined religious groups to regain control over their lives. This account clearly reveals how ethnicity is a labile category, constructed and reconstructed according to the exigencies of external circumstances and reinforced or redirected according to family and group interests.

22. For a sample, see Adrien Katherine Wing, Critical Race Feminism (New York, 1997). 
Drawing upon the work of feminist philosopher Iris Marion Young and historian Sonya O. Rose, Ileen A. DeVault fruitfully deploys John Paul Sartre's concept of seriality to analyze the significance of ethnicity in crossgender strikes in late nineteenth-century United States. ${ }^{23}$ She asks how and why historical actors decide to act upon one identity, for instance class, at one stage in a specific process, only to cast it aside for another identity, for instance ethnicity, at a later stage in the same process, or in circumstances that appear only slightly different. Seriality suggests that all individuals are members of various categories of identification conceptualized as "series", which lie waiting to be "ignited" by external events. Members of the working class or employees in a given workplace are also members of other series, such as gender or ethnicity or community/family. Individuals may act out of each of these series, varying in their response between events, during the unfolding of events, or even over the course of their lives. Identities form out of specific material circumstances, specific events, and by way of the historical narrative, itself a manifestation of seriality. Every individual at any one time has an array of choices of identity and can be an active agent in their construction.

Gender and ethnicity may at times reinforce each other; at other times gender divisions compliment ethnic ones, both of which are intensified by divisions of labor. Still other combinations are possible, as when family and community positions "mute" gender and ethnic divisions. DeVault's cases reveal how workers constantly use notions of ethnicity, class and gender, not only to rally support, but also to identify the enemy, to persuade coworkers to strike or to justify their own cause. The concept of seriality fruitfully directs us away from discussions over which category is the dominant one. Moreover, it accounts for contingency, for "the course of living, that is, of creating historical narrative", as DeVault so elegantly explains.

Laura Dudley Jenkins further highlights the materiality of identity. Rejecting the classification of class as a materially-based category and gender and ethnicity as "identity" categories with no such dimension, she calls for synthesizing economic and cultural analysis. New social movements based on collective identities such as gender, religion, or race, she contends, are material. By moving from Europe or North America to "the developing world" and focusing on women's struggles amid intense cultural diversity and material disparities, Jenkins disrupts current theorizing about identity movements. Identity politics has material consequences, especially when some groups argue for rights on the basis of being "more unequal" than others.

23. Iris Marion Young, "Gender as Seriality: Thinking about Women as a Social Collective", Signs: A Journal of Women in Culture and Society, I9 (1994), pp. 713-738; Sonya O. Rose, "Class Formation and the Quintessential Worker", in John R. Hall (ed.), Reworking Class (Ithaca, NY, 1997), Pp. 133-166. 
In India after Independence, no less than during British rule, the category "woman" fractured along religious and caste lines. Asserting rights equal to men's, some Indian women joined to gain "reservations", or parliamentary seats allocated according to group identity. Their demand, initially fostered by the British to counter more divisive religious and nationalist identities, has pitted women against "other backward classes" and Muslims in the politics of nation building. The Indian experience suggests how groups based on gender, ethnicity, caste, or religion may rally around shared interests. However, as identities overlap, material interests may become as unstable as identity is usually thought to be. Though the construction of women's interests and identities changed over time, the importance of keeping the nation intact triumphed over women's rights. "Competing inequalities" then stymied the development of coalitions to fight structural inequalities.

\section{GENDER, RACE, AND NATION}

Post-colonial studies and policy history offer new directions for historians of class formation and working-class lives. ${ }^{24}$ They have revealed the intricate ways in which race, gender and sexuality connect to citizenship and nation building. The final four articles present intriguing variations on this theme. For Michele Mitchell, racialized discourses of manhood informed the African-American quest for citizenship in the era of imperialism. Indeed gendered notions of respectability for women and manliness for men - as well as education and morality for all - were central to the African-American construction of class, here the silent term behind racialized gendered articulations. Denied the political, civic and economic rights of "real men" at home, elite and aspiring class African-American men advocated their running of empires in Africa and the Philippines. As Mitchell explains, no contradiction necessarily grew from condemning subjugation at home while embracing imperialism as a providential opportunity for uplift of the race. By uncovering the conversation among black elites, she reminds us that men have gender and elites have class but race and nation complicate their meanings. That this story of masculinity and race takes place simultaneously with DeVault's strike narratives highlights the multiple dimensions that exist in one nation at any given time.

Investigation of prostitution, a form of sex work, allows Raelene Frances to chart changing state constructions of class, race, and gender and their

24. For example, Ann Laura Stoler, "Carnal Knowledge and Imperial Power: Gender, Race, and Morality in Colonial Asia", in Micaela di Leonardo (ed.), Gender At the Crossroads of Knowledge: Feminist Anthropology in the Postmodern Era (Berkeley, CA, 1991), pp. 51-Ior; Anne MoClintock, Imperial Leather: Race, Gender and Sexuality in the Colonial Conquest (New York, 1995); Eileen Boris, "The Racialized Gendered State: Conceptions of Citizenship in the United States", Social Politics: International Studies in Gender, State and Society, 2 (1995), pp. 160-180. 
shifting intersections. A settler society, Australia suffered from a gender imbalance as well as a dearth of workers. Establishing class hierarchy and maintaining heterosexuality initially dominated the nation-building project. But popular racism, as well as actual circumstances, turned racial hierarchy into a major issue after settler triumph over indigenous people and importation of non-white laborers. Inequalities in access to women, with the availability of Aboriginal women for white men but management of the sex industry to remove white women from non-white men, expressed social hierarchy in racialized gendered terms. In the early twentieth century, "white Australia" immigration policy became a vehicle for racial and sexual purity as officials deployed it against the entrance of white women reputed to be prostitutes. With the deportation of immigrant colored laborers, labor demands encouraged new attitudes toward the Aboriginals. This change meshed with white middle-class women's fight against the traffic in women, which by the late 1930 s sought to end sexual exploitation of non-white women as well. Control of its sex industry allowed white Australia to cast itself as a "civilized" nation without disrupting racialized and gendered hierarchies of class power. Sex workers would not be citizens.

In early twentieth-century France gendered and racialized bodies became sites of modernization, which reconstructed class relations in the process. Laura L. Frader demonstrates that the new "science of work" was hardly gender or race neutral. In fact, it involved clearly gendered and racialized bodies in interaction with equally gendered and racialized notions about laboring capacity, muscular power, skill and technology. Frader considers gender, race, and class to be mutually constitutive categories of difference. Through the examples of the feminization of racialized colonial male labor during World War I and the deployment of French female labor in the telephone services during the I920s, she exposes the silence of gender in the first case and race in the second. Asian workers lost their masculinity, as they became associated with softness and submissiveness, which made them suitable for unskilled labor in light industries and agriculture. Women's distinct physical and "natural" qualities made them good telephone operators, but as representatives of the French state they could also not be anything else but French and therefore white, and more often from middleclass backgrounds. The Asian worker was inferior not on the basis of race but for not being French. The abstract universalism of the Revolution obscured recognition of the racialized gendered basis of French citizenship. ${ }^{25}$

While adoption of French culture can confer a French identity, Germany still defines citizenship not on the basis of birthplace or culture but in terms of blood. Like pre-World-War-II Australia, Germany connected civilization, racial purity, and national identity. Fatima El-Tayeb joins Frader in 
exposing the racialized gendered assumptions behind science. Such attitudes shape state action, here seen through a sweeping history of Germany's response to interracial relations in three periods: the colonial experience in Africa of the imperial state before World War I, the French occupation of the Rhineland at the time of the Weimar regime, and discussions about Besatzungskinder ("occupation children") of German women and black American soldiers during the Federal Republic. Attitudes toward interracial mixing were surprisingly consistent from the closing decades of the nineteenth century, when German society almost exclusively perceived Africans in terms of their alleged sexuality. El-Tayeb concludes that the definition of Western identity is still very much dependent upon a binary model of "race". Gender and class antagonisms, she argues, are secondary to the West's conception of itself and the way the West perceives its past, present and future. Black people would always be the "other", whatever their gender, class or religion. Race supersedes divisions of gender or class, even when constructed through concepts of gender and sexuality. The only real male was a white male; both the association with non-white sexuality and female sexuality posed a serious threat to manliness. Sexuality here emerges as a socially-constructed category distinctly interrelated with race, class, and gender. From such strands is nationhood and citizenship built.

What happens to class when historians focus on race and gender? It sometimes fades into the background, assumed rather than actively present. This represents a shift from only a decade or so ago when Karen Brodkin Sacks could reasonably claim that "feminist theories and case studies [...] can be read as sustaining the centrality of class and class struggle as key forces for social transformation" ${ }^{26}$ While such scholarship expanded the locations of class, and studies of race and ethnicity have transformed knowledge of social reproduction, class formation, employer strategies, and working-class resistance, ${ }^{27}$ a thoroughgoing rethinking of class is still on the agenda. ${ }^{28}$ We offer these essays as provocations rather than answers.

26. Karen Brodkin Sacks, "Toward a Unified Theory of Class, Race, and Gender", American Ethnologist, 16 (1989), p. 534.

27. See, for example, "Workers in Racially Stratified Societies", thematic issue of International Labor and Working-Class History, sI (1997).

28. See essays in Hall, Reworking Class. 